\title{
CANADA-NOVA SCOTIA OFFSHORE AGREEMENT: ONE YEAR LATER
}

\author{
G. J. DOUCEI Q.C.•
}

\begin{abstract}
The Canada Nove Scotio Agreement on Offshore Oil ond Gos Resource Management and Revenue Sharing has been in effect since Mareh 1. 1982. Afies one year of operoulon. the Agreement has been reviewed to consider whesker the lezal and regulatory framewiortis conducive to proper off shore management. and aiso 10 determize the Agreement's general impaet an the pesroleum industry on the Scottan Shelf.
\end{abstract}

\section{INTRODUCTION}

One of the enduring realities of the Canadian union has been the struggle for supremacy between the Federal government and the ten Provincial governments. While the Constitution Act, 1867 ' created a division of powers, considerable room was left for each level of government to attempt to expand its respective area of responsibility. This has meant that the Courts often have had to determine the proper spheres of jurisdiction for Ottawa and the provinces under the guise of judicial interpretation. In fact, the role of the Courts in this field has had a greater impact than many realize on the way Canadians live.

The jurisdictional disagreement concerning the natural resources located on the Scotian Shelf offshore of Nova Scotia could easily have become a subject of judicial determination. However, a better way was found. During a period of great economic uncertainty and in a province long wary of Ottawa, a negotiated accommodation between the governments of Nova Scotia and Canada was reached in March 1982.2

This accommodation was negotiated by both governments in the hope that offshore oil and gas development would become the single most promising revenue generating resource from and for this area of Canada since Confederation.

The Canada-Nova Scotia Agreement on Offshore Oil and Gas Resource Management and Revenue Sharing was signed by the Government of Canada and the Government of Nova Scotia on March 2, 1982 after a long period of negotiation between these two governments. The Agreement represents a compromise by both parties, and avoids a judicial determination of the constitutional issue of ownership and jurisdiction. The Agreement is for a 42 year term and includes the following declaration in its first paragraph: ${ }^{3}$

It is tbe intention of the parties that this sectement shall survive any decision of the coun whet respect to ownesstip and juriediection...

The Canada-Nova Scotia Offshore Agreement is a political judgment arising from a strong political will by both governments (albeit not for all the same reasons) to have a negotiated agreement.

- Doveer and Aseociares. Halifax. Nova Seotia

1. Formetly the Bntish North America Act. 1867, 30-31 Vict., c. 3 (U. K.) renamed by the Constitutton Aea. 1982

2. On March 2. 1982. Prime Minister Trudeau and Premier John Buchanan signed an agreement entuted Canadn-Nova Scotia Apreement to govern Offshore Oil and Gas Resouree Management and Revenue Sharing.

3. Id 
The Federal government, though confident that a judicial determination of jurisdiction would be in its favour, nonetheless, at that time, needed leverage to persuade Newfoundland to agree to a political settlement of its offshore jurisdiction. The Federal government also had less confidence in the outcome of a judicial determination of Newfoundland's jurisdictional claim, than it did of the Nova Scotia claim. An agreement with Nova Scotia, "for all to see", was felt to be an important opinion maker, if not with the Newfoundland government, then at least with the Newfoundland electorate. (Ironically, it turned out otherwise on both counts because Mr. Peckford won a provincial election on the issue, but went on to lose the jurisdictional issue in the Newfoundland Supreme Courn. $)^{4}$ Finally, the Federal government very much wanted and needed economic activity which could be attributed to its National Energy Program.

The Provincial government in Nova Scotia had its own reasons: it feared a Court outcome on the jurisdictional issue; it needed new economic activity to take up some of the recessionary slack; and it feared that if the Newfoundland issue were resolved first, the more attractive Newfoundland oil exploration would distract industry's attention away from Nova Scotia's natural gas play.

The Nova Scotians were also able to obtain a "most favoured nations clause"s whereby the province has the option, under certain conditions, of replacing its agreement for a better one, for example, a potential CanadaNewfoundland Agreement. This clause, however, expires on January I, 1985 and would appear to be limited to a choice of one agreement or the other, rather than permitting a selection of provisions within either agreement, although the interpretation would likely form the subject of intensive negotiations subsequent to the execution of a Canada-Newfoundland agreement. Should a Canada-Newfoundland agreement not be in place prior to January 1,1985 , it is possible that an extension of this date could also be the subject of negotiation.

\section{LEGISLATION}

The principal statute governing the offshore is now the Canada Oil and Gas Act. ${ }^{6}$ Although neither the Federal Parliament nor the Nova Scotia Legislature has yet enacted legislation necessary to implement the provisions of the Agreement, ${ }^{7}$ they have agreed to govern themselves in accordance with its spirit. The Nova Scotia Legislature must also adopt the Federal Oil and Gas Production and Conservation Act. ${ }^{8}$ The Parliament of Canada will need to enact the provisions of the Agreement. Such legislation may take the form of a "Nova Scotia specific" part to the Canada Oil and Gas Act limited to the Canada Lands defined in the Canadian-Nova Scotia Agreement.

The Agreement, therefore, does not have, at this time, the force of law. Some

4. Refertnee concerning the Mineral and Other Natural Resourees of the Continental Shetf appurenant to the Provizee of Newfoundland. unreported. 17 Fetruary 1983. N.C.A.

5. Suppe n. 2 at s.25.

6. S.C. $1980-81-82-83$, c. 81 .

7. The Nove Scour Legalature has, however, paseed Bill 110 an Act Resperting the Canada-Nove Scotas Oil and Gas Agreement being S.N.S. 1983 c.8. It has not yet been produmed.

8. R.S.C. 1970. c. ond. 
thorny legal issues remain unresolved: do federal or provincial laws apply to the Nova Scotia Offshore? With respect to labour matters, for example does The Canada Labour Code 9 or the Nova Scotia Trade Union Act ${ }^{10}$ apply? It may be a partial answer to deal with this issue by amending the Agreement and by having the amendments enacted by both legislative bodies, providing always that such amendments conform to the Constitution. It should aiso be noted that there is an average three year lag from the time that such bills are introduced into the federal parliament to the time they are enacted. Another concern is that fifty of the sections of the Canada Oil and Gas Act contemplate regulations - most of which have not been promulgated. The old federal oil and gas regulations continue in force to the extent they are not inconsistent with the new Federal Act. In addition, it must not be forgotten that there are also some applicable provincial statutes and regulations which have not been repealed." Practitioners must thus exercise caution in providing legal opinions and practical advice.

The Agreement, by incorporating the Canada Oil and Gas Act 12 provides the basic regulatory framework for the oil and gas industry in Nova Scotia. For example, Section 9 of the Act dealing with Exploration Agreements and Section 10(3) of the Act dealing with Canadian participation in such Exploration Agreements are being applied. Section 21 of the Agreement provides the criteria by which stated objectives of optimum benefit to Canada and Nova Scotia are to be measured. Sections 31 and 32 of the agreement further provide for the transfer and disposition of the Crown share of production prior to authorization of a system for production of oil and gas and Section 13 authorizes the Nova Scotia government to acquire up to a 50 percent portion of the Crown share for a natural gas field and a 25 percent portion of the Crown share in respect of an oil field.

The Agreement provides for jurisdiction of Canadian Courts as follows: ${ }^{13}$

\begin{abstract}
The Federal Coun shall be invested whth juriadiction in the offstore repon in respect of any matter to the same exteat as if the mater had arien within theis ordinary jurisdiction. Proviacial cours stall be invesed with juriadiction in the oftahore region in respect of any matter arising uader the laws made applicable by Partianent to the offshore ropon to the same extent as if the manter had arien withis their ordiany territorial jurisdiction. For the purpose of this paragnaph. the offstore repion shall be decued to be unthin the territorial limits of the County of Halifax.
\end{abstract}

Section 17(d) of the Agreement further provides that:

The Cansdian Governmen shall akk Parliament wo cxtesd its law to apply to activities in tbe offshore and 20 apply to the offstore regions such Nove Seotia laws as may be specified under such lepisiation.

While the Agreement provides many of the answers to potential questions, the first anniversary of the Agreement is too soon for extensive interpretation. Ongoing discussions are proceeding between the two governments on changes ito the Agreement.

9. R.S.C. 1970. C. L-1.

10. S.N.S. 1972 c. 19.

11. Sex. for example. Petroleum and Natural Gas Act. R.S.N.S. 1967, c. 228.

12. Supro n. 6.

13. Suppe n. 2 at s. 17(c). 
Revenue sharing comprises a substantial part of the Agreement. ${ }^{14}$ It is of course still too early to make any sound determination on whether the proper fiscal compromise was made between Ottawa and Nova Scotia and whether enough has been left for industry. It has been suggested that some of the levies may have to be rolled back to allow the necessary rates of retum to enable the Venture Gas Project to proceed.

\section{ADMINISTRATION}

The general administration of the Agreement is carried out by the CanadaNova Scotia Offshore Oil and Gas Board, ("CNS Board") which is composed of three federal and two provincial appointees. The Canada Oil and Gas Lands Administration (COGLA) staff for the Nova Scotia offshore is federally appointed and is based in Halifax. The COGLA staff also acts as staff for the CNS Board. The COGLA staff in Nova Scotia is headed by a public official, Mr. Wynne Potter, with Director General status. He reports to Mr. Maurice Taschereau in Ottawa, who is the overall COGLA Administrator with Assistant Deputy Minister status. Mr. Taschereau chairs the CNS Board. Thus far, the federal government appears, however, to have kept its promise to provide real authority to the COGLA staff administering on behalf of the CNS Board. The role of the CNS Board is expected to expand greatly as activities in the Nova Scotia offshore continue to move forward and as projects move into development and production.

A crucial element of the internal working of the CNS Board is the possibility of its Nova Scotia members invoking "suspension rights" whereby Nova Scotia members of the CNS Board delay for a period of 18 months the execution of certain decisions concerning resource management. This delay can be activated by both Nova Scotia members voting against the federal membership majority. These suspension rights, though qualified, are obviously intended to provide an opportunity for the political negotiation of a decision acceptable to both governments. The province has not, to date, made use of this provision, a fact which reflects the desire of both governments to demonstrate that the Agreement is working.

\section{SOME EXPERIENCES IN THE APPLICATION OF THE ACT}

Under the Canada Oil and Gas Act, is an Exploration Agreement may be made under ministerial discretion without a call for proposals. Subsection 12(1) of the Act provides as follows:

\footnotetext{
The Miasster may enter into an exploration apreement witbout a notice calling for a submisston of proposals where the Miniater does not consider is to be in tbe public interen to pive sueb nouce omag to the area or location of the aveilable Cansda lands of the neod to ser expeditioualy.
}

In mid-1982, only a few months after the Act was passed and the Agreement signed, this "exception" clause was activated to grant an Exploration Agreement to a consortium of Petro-Canada, Bow Valley and Husky, covering

14. Supre a. 2.

15. Supre n. 6. 
4.2 million acres of "Canada Lands" in the Nova Scotia offshore. ${ }^{16}$ This exception was related to the Canadian content composition of the consortium and the desire of the two governments to give an early high profile to the agreement. It is doubtful, however, that this exception clause will be activated often, at least in the Nova Scotia offshore, in the foreseeable future.

There are some who believe that the provisions of the Canada Oil and Gas Act, ${ }^{17}$ with its many areas of "Ministerial Discretion", make it virtually impossible to certify title to the lands which fall under its ambit. This uncertainty presents problems. How, for example, does a lender take adequate security? There is no registry system in place under the Federal Act and regulations. This problem of taking security may have more relevance in future activities in the Nova Scotia offshore than it has had in the North Sea (in Norway, for example) where the issue of obtaining adequate security has been less important because the majority of the explorers have been multi-nationals with a financial capacity which does not require debt financing.

To date, the only instance in which a lender has taken debt security on Canada Lands under the new regime occurred in the case of East Coast Energy Ltd. Bridge financing with a chartered bank was required prior to an equity issue by the company. The law firm acting for the company was able to obtain from the Federal Minister of Energy, Mines and Resources a certificate of prior approval in favour of the lender in case of the borrower's default, conditional, however, upon the lender disposing of the working interest to an "eligible purchaser", defined as a Canadian resident or a Canadian controlled corporation with a Canadian ownership rate of at least fifty percent.

(The borrower did not default.) It is clear that there cannot be "transfers" without ministerial approval. As of May 1, 1983, the following chart represents the Exploration Agreements in respect to Canada Lands which have been entered into under the new Federal-Provincial regime: ${ }^{18}$

16. This anmouncement was made in Halifax joindy by Premier Jobn M. Buchanan of Nova Scouk and the Federal Mininter of Enerty. Mines and Resources on July 30. 1982.

17. Supre a. 6.

18. Enabliabed pursuant to the Ottawa-Niova Seotia offshore agreement and the Canada Oil and Gas Act. S.C. $1980-81-22-83$ c. 81 . Source: COGLA records. 


\section{EXPLORATION AGREEMENTS}

(April 1983)

\begin{tabular}{|c|c|c|c|c|c|c|c|}
\hline $\begin{array}{l}\text { Operatias } \\
\text { Compantiyy }\end{array}$ & $\underset{\text { Daxte }}{\text { Entective }}$ & 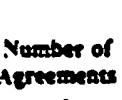 & $\begin{array}{l}\text { Area } \\
\text { (Mullios } \\
\text { Hectares) }\end{array}$ & Location & Tores & $\begin{array}{c}\text { Weth } \\
\text { Commitumeat }\end{array}$ & $\begin{array}{l}\text { Program Valoe } \\
\text { (Millioo SCda) }\end{array}$ \\
\hline Esso & Apr. 1982 & 6 & 2.4 & $\begin{array}{l}\text { Mackenzie } \\
\text { Delsa - } \\
\text { Beauforn Sea }\end{array}$ & $S$ yrs. & $\begin{array}{l}\text { S-Offshore } \\
\text { 4-Onshore }\end{array}$ & 600 \\
\hline Canterra & Apr. 1982 & 1 & 0.8 & Davis Strait & 5 yrs. & 2 & 200 \\
\hline $\begin{array}{l}\text { Petro-Canada } \\
\text { (Husky-Bow } \\
\text { Valley) }\end{array}$ & July 1982 & 4 & 1.7 & Scotian Shelf & 3 yrs. & 8 & 500 \\
\hline \multirow[t]{2}{*}{ Shell } & Mar. 1982 & 6 & 3.8 & Scotian Slope & $\begin{array}{l}2-6 \text { yrs. } \\
4-4 \text { yrs. }\end{array}$ & 6 & 263 \\
\hline & Nov. 1982 & 7 & 1.9 & Scotian Shelf & 3 yrs. & 9 & ss! \\
\hline Panarctic & Sept. 1982 & 20 & 14.0 & Aretic Islands & 5 yrs. & 25 & 700 \\
\hline Mobil & $\begin{array}{l}\text { July } 1982 \text { (2) } \\
\text { Jan. } 1983 \text { (1) }\end{array}$ & (2) 3 & 1.3 & Scotia Shelf & $\begin{array}{l}18 \text { mos. } \\
\text { to } 4 \text { yrs. }\end{array}$ & 6 & 310 \\
\hline \multirow[t]{2}{*}{ Gulf } & Mar. 1983 & 1 & .6 & Beaufor Sea & $S$ yrs. & $s$ & $\begin{array}{c}436 \text { (Operating) } \\
674 \text { (Capital) }\end{array}$ \\
\hline & Jan. 1983 & 1 & .4 & $\begin{array}{l}\text { West } \\
\text { Beaufort Sea }\end{array}$ & S yrs. & 1 & 914 \\
\hline Dome & $\begin{array}{l}\text { Sept. } 1982 \\
\text { July } 1982\end{array}$ & $\begin{array}{l}5 \\
1\end{array}$ & $\begin{array}{c}3.5 \\
.24\end{array}$ & $\begin{array}{l}\text { Beaufort Sea } \\
\text { East Sable }\end{array}$ & $\begin{array}{l}5 \text { yrs. } \\
24 / 2 \text { yrs. }\end{array}$ & $\begin{array}{l}8 \\
1\end{array}$ & $\begin{array}{l}960 \\
113\end{array}$ \\
\hline Chevron & Jan. 1983 & 2 & 1.1 & $\begin{array}{l}\text { Gulf of } \\
\text { St. Lawrence }\end{array}$ & 3 yes. & 2 & 28 \\
\hline $\begin{array}{l}\text { Labrador } \\
\text { Group }\end{array}$ & Mar. 1982 & 10 & 9.0 & $\begin{array}{l}\text { Labrador } \\
\text { Shelf }\end{array}$ & 5 yrs. & 10 & 500 \\
\hline BP & Mar. 1982 & 6 & 5.3 & $\begin{array}{l}\text { Labrador } \\
\text { Shelf }\end{array}$ & $\begin{array}{l}4-4 \text { yrs. } \\
2-5 \text { yrs. }\end{array}$ & 6 & 265 \\
\hline
\end{tabular}

As of May 1, 1983, there remained to be finalized licences affecting four companies granted under the previous authorities.

A prominent component of these new Exploration Agreements is the surrendering of licenced land back to the Crown. As of May 1, 1983, one such surrender had already been registered. This land and other lands thus surrendered will likely be posted for competitive bidding particularly if explorers express an interest in this being done. There also exists "vacant" land in the Nova Scotia offshore, but thus far no substantial interest to explore has been expressed to COGLA.

\section{ECONOMIC IMPACT}

While it may be too early to determine if the Agreement is a suitable long term compromise it can certainly be examined to determine whether the regulatory framework is working satisfactorily for both industry and government, and if it has thus far proven to be in the public interest.

Since March, 1982, there has been an accelerated commitment by the oil and gas industry to the Scotian Shelf. When announcing a new Exploration 
Agreement in Halifax on April 15, 1983, the Honourable Allan J. MacEachen. Canada's Deputy Prime Minister, stated that: ${ }^{19}$

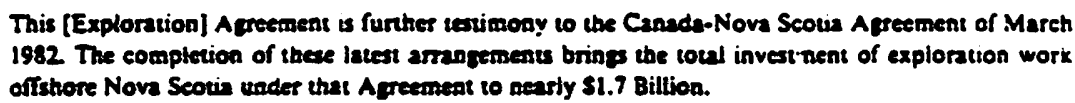

By Nova Scotia standards, a $\$ 1.7$ billion commitment ثuring a one-year period is very respectable. That figure, however, is expected soon to be dwarfed by development expenditures, starting with the Sable Island Venture Project, estimated at $\$ 4$ billion.

There is no doubt that this activity would not be occurring at this time without Ottawa and Nova Scotia having reached a political settlement in the form of the Agreement. The establishment of certainty with respect to the rules of the game has been an important positive factor. There are currently six rigs drilling off Nova Scotia, which should increase to eight by the end of 1983 . There is, in addition, a very strong push to have a producing natural gas industry offshore Nova Scotia by as early as 1987.

Mobil Oil Canada Ltd., recently released its Environmental. Impact Statement concerning the Venture Gas Project. Volume I of their submission discusses the location and reserves at Venture as follows: 20

\begin{abstract}
The Venture Field is situsted about $16 \mathrm{~km}$ ( $10 \mathrm{mi}$ ) eass of the North East tip of Sable laland and covers an ares of approximetely $38 \mathrm{~km}$ ) - The water depth in this area is a relatively shallow $22 \mathrm{~m}$ ( $72 \mathrm{ft}$.).

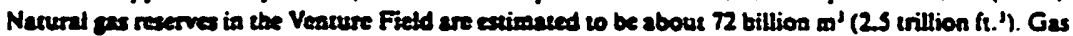
production from the field will be approximutely 11.3 millios $\mathrm{m}^{3}$ (360 million f.') per day. Production will betin to deeline in the 16 b year. The expected life of the field is 18 years. Based on current

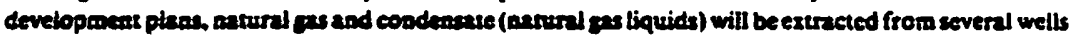
drilled to develop the field. undergo proliminary trentment on offshore facilities and be transported by sebses pipatioc to cosbore freiltive.

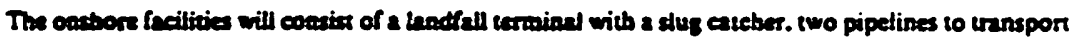
the pes and condenate overtand, and procuing facilities where gas sales and liquid products will be produced Mobil will use existing offebore cochnology is the development of the Venture Gas Field. Condivioas at the Verture sice are similar to chber aress of offhbore production (c.g.. Itre Southern portion of the North Ser). and the rectinology has ben proven.
\end{abstract}

The increased number of rigs operating on the Shelf since March, 1982 and the continuing progress of the development of the Venture Gas Project are taking place at a time of anticipated positive long term opportunities for export sales of Nova Scotia gas to American markets, notwithstanding the current United States natural gas glut.

The National Energy Board in its recent natural gas licensing export approvals assumed, for the first time, that natural gas from Nova Scotia could be marketed in the American east coast market. ${ }^{21}$ There are interested American buyers, providing the price is right. An article in the Halifax Chronicle Herald in March 1983 focused on the objectives of Houston-based

19. Helfox Chroniele-Herald. 16 Aprit. 1983.

20. Vol. 1. Summary Venture Development Project. Environmental Impact Statement. Section 2.1 at p. 8. Feb 1983.

21. Nawonal Eserty Board Reasons for Decision in the Matter of the gas export omnibus heariag 1982. Dated January. 1983. 
Transco in its bid to buy Sable Island gas. Senior Gas Purchaser Manager for Transco, Mr. Roger Cooper, explained Transco's position:22

\footnotetext{
If we are sucessuful in our bud to buy Sable Isiand gas. It will mean a long-1erm supply for us and a strong market for Sable lsiand gas. . Amertean sirms would iske to buy all the gas that isn't used domestically in Nova Scotra.
}

Transco, along with Texas Eastern, Algonquin and Nova have formed a partnership, the New England States Pipeline Group, proposing to build a 360-mile gas pipeline from New Brunswick-iMaine Border at St. StephenCalais to connect with Algonquin's system at Burrillville, Rhode Island. An article in Atlantic Energy News ${ }^{23}$ makes reierence to the active interest in Nova Scotia gas of a consortium of Linited States gas distribution companies grouped together under the name of Northeast Gas Markets Inc. for the purpose of purchasing Sable Island gas. In addition, Tennessee, one of two pipeline companies in New England, has been actively promoting its interest in buying Nova Scotia gas.

All of this has created a mood of optimism in Nova Scotia concerning offshore oil and gas development. The metropolitan area of Halifax/Dartmouth is especially gearing up. Statistics Canada recently reported that unemployment in Halifax was among the lowest in all of Canada. ${ }^{24}$

For the Venture Project to proceed some critically important variables still need to be determined, including the confirmation of the reserves in the Venture area and a pricing regime to make the gas competitive. It is expected that the former will be accomplished by the current program of drilling in the Venture area and the latter may be a function of a rollback of federal and provincial taxes on Sable gas or a new Canada-United States border price formula or both.

There is no doubt that federal-provincial cooperation in the form of this Agreement has expedited a significant upsurge in exploration activity for oil and gas in the Nova Scotia offshore. Drilling activity on Canada Lands generally has not increased during this period anywhere except in Nova Scotia.

The Agreement and the consequent drilling activity are criticaily important to the hopes and dreams of Nova Scotians and Maritimers, and also it is hoped to Canadians as a whole.

22. Halifex ChroutelenHerald, 10 Mareh. 1983.

23. Ailente Energy News. April ed.. p. 10.

24. Lobour Fonce, May. 1983. 